\title{
LATE MIOCENE BONY FISHES FROM POCŞEŞTI (REPUBLIC OF MOLDOVA)
}

\author{
O. M. Kovalchuk', V. A. Marareskul ${ }^{2}$, T. F. Obadă ${ }^{3}$ \\ ${ }^{1}$ National Museum of the Natural History, NAS of Ukraine \\ 15, B. Khmelnytskyi St., Kyiv 01601, Ukraine \\ ${ }^{2}$ The State Service of Geology and Subsoil of Transnistria, 58/3, Yunosti St., Tiraspol MD-3300 \\ 3/nstitute of Zoology, AS of the Republic of Moldova \\ 1, Academicheskaya St., Chişinău 2028, Republic of Moldova \\ e-mail: Biologiest@ukr.net
}

Isolated pharyngeal and jaw teeth of bony fishes, as well as numerous bones of other vertebrates dated by Late Miocene (middle late Sarmatian s.I. = early Tortonian, 9.8 Ma), were found in the alluvial sediments of Pocşeşti site (Republic of Moldova). Six fish taxa were identified and described in the paper; the majority of them (4 species) are representatives of Cyprinidae family. Taxonomic list also includes sturgeons (Acipenseridae gen. et sp. indet.) and pikes (Esox sp.). Mixed character of fauna, joint presence of freshwater and marine species suggests that the burial of remnants took place in close proximity to large marine basin in river avandelta. Fish assemblage of Pocşeşti shows an affinity to other early Tortonian localities in Europe and reflects paleobiogeographic changes on the territory of Paratethys during the Late Miocene.

Keywords: bony fishes, Late Miocene, Sarmatian s.I., MN 10, Pocşeşti, Eastern Europe.

\section{INTRODUCTION}

European bony fish fauna began to be formed in the second half of the Paleogene. This process was continued in the Neogene, accompanied by a large-scale restructuring of ecosystems on the background of significant climatic changes. Numerous remnants of freshwater and marine bony fishes from the Late Miocene of Eastern Europe need careful handling and detailed study.

Pocşeşti (Pokshesht) site was discovered by G.M. Bilinskis in 1975 [11] and is dated to Balta suite. It is located near eponymous village on the border of Orgeevskyi and Strashenskyi districts in the Republic of Moldova (Fig. 1). Fossil bones are concentrated on the right side of Ikel River valley at the attitude of 195-200 m. According to palaeomagnetic analysis, provided by I.A. Pevzner with colleagues [18], fosilliferous horizon of Pocşeşti has right magnetization and dated to the $9^{\text {th }}$ epoch of magnetic polarity (between 10 and $9 \mathrm{Ma}$ ).

ISSN 1996-4536 (print) • ISSN 2311-0783 (on-line) • Біологічні Студії / Studia Biologica • 2014 • Том 8/№2 • С. 149-156 


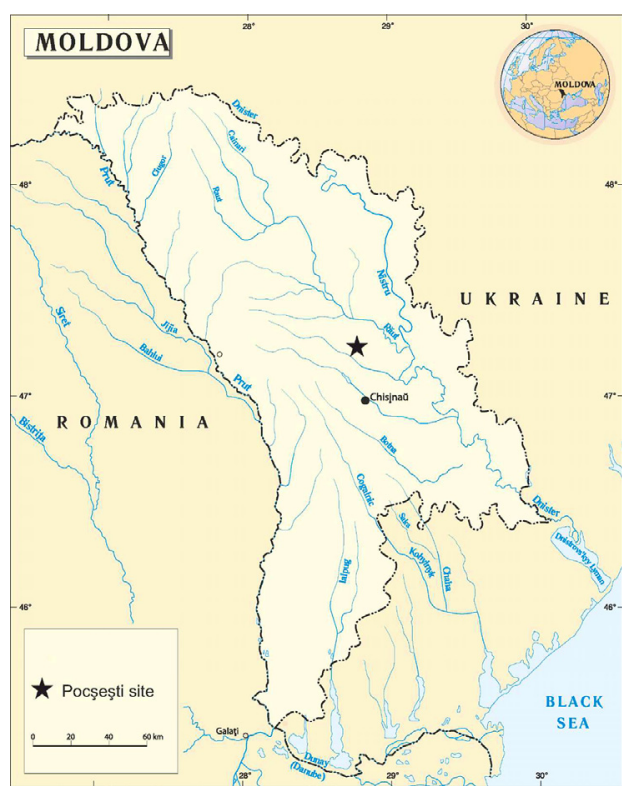

Fig. 1. Location map of the late Miocene Pocşeşti locality

Рис. 1. Розташування пізньоміоценового місцезнаходження Покшешти
The following vertebrates are known from the Pocşeşti site: mammals (Lagomorpha: Proochotona cf. kalfense Lungu, 1981, Alilepus sp.; Rodentia: Neocricetodon (Kowalskia) sp., Collimys sp.; Sirenia: Dugongidae (cf. Metaxytherium), Dugongidae indet.; Cetacea: Physeteroidea indet., Delphinidae indet.; Carnivora: Parataxidea sp., Protictitherium sp., Metailurus cf. parvulus (Hensel, 1862), Machairodus cf. giganteus Wagner, 1848; Proboscidea: Tetralophodon longirostris Kaup, 1835; Perissodactyla: Hipparion aff. verae Gabunia, 1959, Hipparion aff. giganteum Gromova, 1952, Chilotherium (Acerorhinus) cf. zernovi Borissiak, 1914, Chilotherium (Chilotherium) aff. sarmaticum Korotkevich, 1958; Artiodactyla: Achtiaria aff. moldavicus Godina, 1975, Miotragocerus leskevitschi (Borissiak, 1914), Gazella (Miogazella) schlosseri Pavlow, 1913, Gazella cf. deperdita Gaudry, 1873, birds (Struthio sp.), reptiles (Protestudo sp.) and amphibians (Hyla sp., Bombina sp.) [6, 11-14].

Here we describe fossil bony fish bones from the middle late Sarmatian strata of Pocşeşti site.

ABBREVIATIONS USED IN TEXT: IZ - Institute of Zoology of the Academy of Sciences of the Republic of Moldova; Poc - locality Pocşeşti.

\section{MATERIAL AND METHODS}

The present article is based on the study of 12 fish bones, 8 of which are determinable to species or at least to genus level. The investigated material was collected by A.N. Lungu in 1980s and also V.A. Marareskul and T.F. Obada during the 2011-2013.

Collection of fossil fishes from Pocşeşti was obtained by the screen-washing (mesh diameter $=1.0 \mathrm{~mm}$ ) of the bonyferous rock from the $6^{\text {th }}$ layer and recently is housed in the IZ. This material contains by the following specimens: 1 - pharyngeal tooth Leuciscus sp. (IZ Poc/01); 2 - pharyngeal tooth Rutilus frisii (IZ Poc/02); 3 - pharyngeal tooth Scardinius sp. (IZ Poc/03); 4 - pharyngeal tooth Tinca sp. (IZ Poc/04); 5 - jaw tooth, 2 vertebrae Esox sp. (IZ Poc/05-07); 8-10 - 3 vertebrae (IZ Poc/8-10); 11 - fragment of dermalia Acipenseridae (IZ Poc/11); 12 - fragment of dermalia (IZ Poc/12).

A direct determination of fossil remnants was provided by authors using diagnostic features. For comparative purposes bones from the osteological collections of the National Museum of Natural History NAS of Ukraine were used. Ichthyologic systematics in this paper follows Yu.V. Movchan [15].

Current correlation of the Paratethys stages with European Mammal Neogene Zones was essentially taken from V.A. Nesin and A. Nadachowski [16]. Measurements were taken with digital caliper, with accuracy to $0.1 \mathrm{~mm}$. Fossil remnants were photographed 
using the research microscope Leica M168C. Pharyngeal tooth terminology, used in the article, follows E. Rutte [21], E.K. Sytchevskaya [24] and J. Lepiksaar [9] (Fig. 2).

\section{GEOLOGICAL SETTING}

The following layers were identified by A.N. Lungu in 1979 [11] in the geological section of Pocşeşti:

1) Top soil, 0.2-0.3 m;

2) Brown loam, 0.2-0.4 m;

3) Lumpy non-laminated greenish-gray clay with nodules of carbonates and charred plant remnants, $1.8 \mathrm{~m}$;

4) Sandy gray clay with calcareous concretions, gradually moving up in dark green lumpy clay with bones of terrestrial vertebrates, $0.5 \mathrm{~m}$;

5) Lumpy non-laminated gray clay with
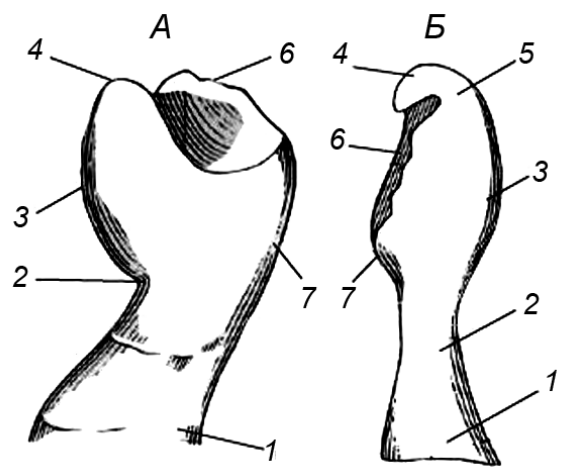

Fig. 2. Morphology of the pharyngeal teeth of carp fishes [24]: 1 - pedicle; 2 - tooth neck; 3 - tooth back; 4 - hook; 5 - hook base; 6 - grinding surface; 7 - tooth belly

Рис. 2. Морфологія глоткових зубів коропових риб [24]: 1 - ніжка; 2 - шийка зуба; 3 спинка зуба; 4 - гачок; 5 - основа гачка; 6 - жувальна поверхня; 7 - черевце charred plant remnants and fragments of vertebrate bones, $0.5-1.0 \mathrm{~m}$;

$6)$ Sandy gray clay, contain with clay nodules and bones of terrestrial vertebrates, 1.0-2.5 m;

7) Fine clay, slightly cross-bedded sand with gravel lenses, 0.5-2.5 m;

8) Sandy shaly gray clay with rusty spots, $1.5-2.0 \mathrm{~m}$.

Khersonian deposits on the Moldavian plate are composed by clastic sediments [20]. On the described territory only lower horizon is clearly identified and represented by marine greenish-gray clays interbedded with siltstone and fine-grained quartz sand.

Upper horizon is composed by alluvial sediments and is not separated from younger lithologically similar Balta suite formations. Balta sandy-clay deposits are widespread within the central and southern part of the Dniester-Prut interfluve and between Dniester - Southern Bug. Formation time of these sediments is associated with the end of the middle Sarmatian to Pontian. They are represented by lake-marsh, river, and deltaic facies. Their stratigraphic division is not clear [8].

\section{SYSTEMATIC PALEONTOLOGY}

ACIPENSERIFORMES Berg, 1940

Family ACIPENSERIDAE Bonaparte, 1831

Acipenseridae gen. et sp. indet.

Referred specimen: fragment of dermalia (IZ Poc/11).

Description: Small dermal fragment $(I=8 \mathrm{~mm})$ is preserved. There are small rounded recesses with smooth edges on the bone surface. Dense bone is laminar and so broken.

CYPRINIFORMES Goodrich, 1909

Family CYPRINIDAE Fleming, 1822

Leuciscus Cuvier, 1816

\section{Leuciscus sp.}

Referred specimen: pharyngeal tooth (IZ Poc/01) (Fig. 3, 1). 


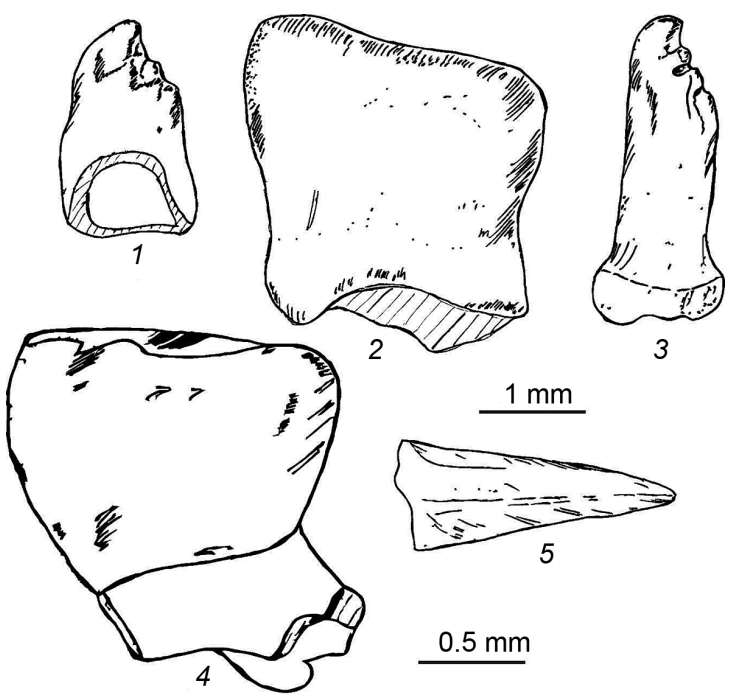

Fig. 3. Fossil bony fish bones from the Pocşeşti site in Moldova: 1 - Leuciscus sp. (IZ Poc/01); 2 - Rutilus frisii (IZ Poc/02); 3 - Scardinius sp. (IZ Poc/03); 4 - Tinca sp. (IZ Poc/04); 5 - Esox sp. (IZ Poc/05)

Рис. 3. Кістки викопних костистих риб із місцезнаходження Покшешти у Молдові: 1 - Leuciscus sp. (IZ Poc/01); 2 - Rutilus frisii (IZ Poc/02); 3 - Scardinius sp. (IZ Poc/03); 4 - Tinca sp. (IZ Poc/04); 5 - Esox sp. (IZ Poc/05)

Description: Pharyngeal tooth is slender, with relatively low rounded crown, broken at the base. Tooth back is straight, top of the tooth is elongated in the blunt robust hook. Its edge is targeted forward and upward. Grinding surface has two small jags. Tooth belly is slightly convex. Height of the crown is 2.3 , width is $1.4 \mathrm{~mm}$. Tooth belongs to small (juvenile?) specimen.

Rutilus Rafinesque, 1820

\section{Rutilus frisii (Nordmann, 1840)}

Referred specimen: pharyngeal tooth (IZ Poc/02) (Fig. 3, 2).

Description: Tooth is rough, with fungiform, laterally compressed crown. Tooth back is convex and arcuate, top without hook. Grinding surface is narrow, slightly convex, with weekly marked longitudinal furrow and has traces of intravital obliteration. Tooth belly is convex and hangs over the neck. Pedicle is partly broken, oval in the crosssection. Crown is coarcted to neck and a little larger than its width. Height of the tooth is 3.2 , width of the crown is $3.1 \mathrm{~mm}$.

\section{Scardinius Bonaparte, 1837}

\section{Scardinius sp.}

Referred specimen: pharyngeal tooth (IZ Poc/03) (Fig. 3, 3).

Description: Small pharyngeal tooth on the long pedicle has high laterally slender cylindrical crown with broad base. Tooth back is straight, with robust hook at the top. Grinding surface is narrow with a higher edge that has 3 robust pointed jags and a lower edge without jags. Tooth belly is rounded and compressed, without keel. Height of the tooth is 3.2 , width of the crown is $1.5 \mathrm{~mm}$.

Tinca Cuvier, 1816

\section{Tinca sp.}

Referred specimen: pharyngeal tooth (IZ Poc/04) (Fig. 3, 4).

Description: Flattened pharyngeal tooth has low crown. Pedicle is rounded and slightly deflexed. Neck is expressed well, tooth back is convex and arcuate. Tooth belly is also slightly convex. Grinding surface is narrow, laterally compressed, having a deep 
longitudinal wrinkle with slightly convex roller edges. Wrinkle on the lower edge of the grinding surface is jagged by transverse corrugations and forms a fin scroll on the posterior surface of the crown. Height of the tooth is 5.6, width of the crown is $5.8 \mathrm{~mm}$.

ESOCIFORMES Bleeker, 1858

Family ESOCIDAE Cuvier, 1816

Esox Linnaeus, 1758

Esox sp.

Referred specimen: jaw tooth, 2 vertebrae (IZ Poc/05-07) (Fig. 3, 5).

Description: The long, slender, pointed tooth has two sharp edges. Its conical crown with slightly worn apex is partly broken. Cross-section is interiorly smooth and exteriorly convex. Height of the tooth is $5.5 \mathrm{~mm}$, width of the crown is $2.1 \mathrm{~mm}$. The attribution of vertebrae to pike was based on morphological similarities and remains more unclear.

\section{DISCUSSION}

All the above-mentioned bony fish species from Pocşeşti were identified based on single disarticulated specimens. Nevertheless, it is possible to provide a view on composition fish community in the late Sarmatian of that area. It includes reophiles (Leuciscus, Rutilus) and limnophiles (Scardinius, Tinca, Esox). Fishes from Pocşeşti are presented by four different trophic groups (herbivorous, malacophagous, piscivorous and omnivorous).

The majority of identified fish taxa (4 species) are representatives of the family Cyprinidae. Other families (Acipenseridae, Esocidae) are presented by single species. It must be noted that all identified genera are still available in the recent Dniester River delta fish community [4, 23].

Fish fauna from Pocşeşti is mixed - freshwater and marine species are presented together. It suggests that the burial of remnants took place in close proximity to large marine basin in the river avandelta [17]. Described fish assemblage shows affinity to other late Sarmatian (early Tortonian) localities in Europe on faunistic composition and taxonomic diversity. It is the most similar to Mikhailovka on Bug 1 and 2 in Ukraine (all species are common, except Acipenseridae). Bony fish complex from Pocєeєti can be also compared with Sandberg near Gözendorf in Austria (remnants of Leuciscus, Rutilus, Scardinius and Tinca are common for both localities) [1, 5, 7], Schernham b. Haag (Rutilus, Scardinius, Tinca) [3], Hammerschmiede 1 and 3 (Leuciscus and Esox) [2], Höwenegg in Germany (Rutilus and Tinca) [26] and Borský Svätý Jur in Slovakia (Scardinius and Tinca) [3]. Other late Sarmatian localities (Csákvár in Hungary [3], Kocgasi ASK and Sofca in Turkey [3, 22], Baghmisheh-Marzdaran, Tabriz-Basin in Iran [19], München-Aufmeister (Isarufer) in Germany [26] and Richardhof-Golfplatz in Austria [7]) are less similar to the fish community of Pocşeşti.

Taxonomic composition of terrestrial oriktokomplex from Pocşeşti indicates its archaic appearance and brings it with hipparion fauna from Varnitsa, as well as hipparion assemblages from Eldar in Transcaucasia, Berislav and Grebeniki in Ukraine [10]. Terrestrial fauna of Pocşeşti occupies an intermediate position between the earliest and late hipparion faunas on the Northern Black Sea Coast and stands as an independent faunal complex [12]. Most of its representatives inhabited savanna landscapes of the steppe type, as well as wetlands, forested floodplains and riparian forests [10,12]. This community suggests be related to the first half of the late Sarmatian s.I. (9.8 Ma, MN10).

ISSN 1996-4536 (print) • ISSN 2311-0783 (on-line) • Біологічні Студії / Studia Biologica • 2014 • Том 8/№2 • С. 149-156 


\section{CONCLUSIONS}

1. Six bony fish taxa of 6 genera, 3 families (Acipenseridae, Cyprinidae, Esocidae) and 3 orders (Acipenseriformes, Cypriniformes, Esociformes), dated to the late Sarmatian s.I., were identified in the alluvial sediments of Pocşeşti site (Republic of Moldova, Eastern Europe).

2. Mixed character of fauna, joint presence of freshwater and marine species, suggests that the burial of remnants took place in close proximity of large marine basin in the river avandelta.

3. Bony fish assemblage of Pocşeşti is more or less similar to other late Sarmatian (early Tortonian) localities within the territory of Paratethys on faunistic composition and taxonomic diversity.

4. Described community can be dated by the first half of the late Sarmatian s.I. (= early Khersonian, early Tortonian, 9.8 Ma, MN10).

We sincerely thank to Dr. Stanislav Čermak (Prague, Czech Republic) who corrected our English, and Oleksandr Holovko (Kyiv, Ukraine) for his help in the technical preparation of the manuscript.

1. Böhme M. Freshwater fishes from the Pannonian of the Vienna Basin with special reference to the locality Sandberg near Götzendorf, Lower Austria. Courier Forschungsinstitut Senckenberg, 2002; 237: 151-173.

2. Böhme M. The Miocene Climatic Optimum: evidence from ectothermic vertebrates of Central Europe. Palaeogeography, Palaeoclimatology, Palaeoecology, 2003; 195: 389-401.

3. Database of Vertebrates: fossil Fishes, Amphibians, Reptiles and Birds (fosFARbase) localities and taxa from the Triassic to the Neogene. www.wahre-staerke.com.

4. Dolgy V.N. Current state of ichthyofauna of the Dniester Basin within Moldova. Biodiversity Conservation in the Dniester River Basin: proceedings of the scientific conference (Chişinău, October 7-9, 1999). Chişinău: Biotica Ecological society, 1999: 61-62. (In Russian).

5. Gaudant J. Die Fischfauna aus dem Ober-Pannonien von Götzendorf an der Leitha, Niederösterreich. Annalen des Naturhistorischen Museums in Wien, 1994; 96A: 117131. (In German).

6. Gol'din P.E., Marareskul V.A. Miocene Toothed Whales (Cetacea, Odontoceti) from the Dniester Valley: The First Record of Miocene Sperm Whales (Physeteroidea) from the Eastern Europe. Vestnik Zoologii, 2013; 47(5): 409-414.

7. Harzhauser M., Tempfer P. Late Pannonian Wetland Ecology of the Vienna Basin based on Molluscs and Lower Vertebrate Assemblages (Late Miocene, MN 9, Austria). Courier Forschungsinstitut Senckenberg, 2004; 246: 55-68.

8. Hubka A.N. Main reguliarities of formation of the Upper Sarmatian sediments in the DniesterPrut interfluve. Izvestiya AN MSSR, Series of Biological and Chemical Sciences, 1962; 4: 35-43. (In Russian).

9. Lepiksaar J. Introduction to osteology of fishes for palaeozoologists. Göteborg, 1994. $96 \mathrm{p}$.

10. Lungu A.N. Early developmental stages of the hipparion fauna in continental framing of Paratethys. Doctoral Thesis. Tbilisi, 1990. 36 p. (In Russian).

11. Lungu A.N., Bilinskis G.M. A new locality of hipparion fauna in Baltic sediments of the Central Moldova. Izvestiya AN MSSR, Series of Physical-technical and Mathematical Sciences, 1979; 2: 79-85. (In Russian).

12. Lungu A.N., Chemyrtan G. To the developmental history of the Late Sarmatian hipparion fauna of northern areas of the continental framing of Eastern Paratethys. Trudy Gosudarstvennogo Kraevedcheskogo Muzeya MSSR, 1989; 3: 48-66. (In Russian). 
13. Lungu A.N., Rzebic-Kowalska B. Faunal assemblages, stratigraphy and taphonomy of the Late Miocene localities in the Republic of Moldova. Institute of Systematics and EvoIution of Animals, Polish Academy of Sciences, Krakow, 2011. 62 p.

14. Marareskul V.A. The first confirmed record of a sirenian (Mammalia: Sirenia) from the Late Miocene of Moldova. Proceedings of the $34^{\text {th }}$ Session of Paleontological Society NAS of Ukraine. Kyiv, 2012: 116-118. (In Russian).

15. Movchan Yu.V. Fishes of Ukraine. Kyiv: Zoloti Vorota, 2011. 444 p. (In Ukrainian).

16. Nesin V.A., Nadachowski A. Late Miocene and Pliocene small mammal faunas (Insectivora, Lagomorpha, Rodentia) of Southeastern Europe. Acta Zoologica Cracoviensia, 2001; 44(2): 107-135.

17. Obada T.F., Marareskul V.A. Additional data on the taphonomy and systematic diversity of the Upper Sarmatian (Khersonian) fauna from Pocsesti, Republic of Moldova. The $\mathbf{9}^{\text {th }}$ Romanian Symposium on Paleontology (lasi, October 25-26, 2013). lasi, 2013: 72-73.

18. Pevzner I.A., Lungu A.N., Vangengeym E.A., Basilyan A.E. Occurrences of Vallesian-age hipparion fauna in Moldavia and their placement on the magnetic polarity scale. International Geological Review, 1987; 29(2): 140-150.

19. Reichenbacher B., Alimohammadian H., Sabouri J. et al. Late Miocene stratigraphy, palaeoecology and palaeogeography of the Tabriz Basin (NW Iran, Eastern Paratethys). Palaeogeography, Palaeoclimatology, Palaeoecology, 2011; 311(1-2): 1-18.

20. Roshka V.H., Hubka A.N. Essay on stratigraphy of Neogene sediments of the Dniester-Prut interfluve. Biostratigraphy of Anthropogene and Neogene of southwestern USSR. Chişinău, 1981: 78-106. (In Russian).

21. Rutte E. Schlundzahne von Süsswasserfischen. Palaeontographica, 1968; 120 (4-6): 165212. (In German).

22. Sickenberg $O$. Die Gliederung des höheren Jungtertiärs und Altquartärs in der Türkei nach Vertebraten und ihre Bedeutung für die internationale Neogen-Stratigraphie. Geologisches Jahrbuch Reihe B Heft, 1975; 15: 1-167. (In German).

23. Snigirev S.M. Biodiversity of ichthyofauna in the Dniester River delta. Ecology of cities and recreational areas: proceedings of the all-Ukrainian conference (Odesa, June 2-3, 2011). Odesa, 2011: 142-144. (In Russian).

24. Sytchevskaya E.K. Freshwater Neogene Ichthyofauna of Mongolia. Transactions of the joint Soviet-Mongolian paleontological expedition. Moscow: Nauka 39: 144 p. (In Russian).

25. Tobien H. Die jungtertiäre Fossilgrabungsstätte Höwenegg im Hegau (Südwestdeutschland). Ein Statusbericht. Carolinea, 1986; 44: 9-34. (In German).

26. WeilerW. Pisces. In: Stromer E. Wirbeltiere im Obermiozänen Flinz Münchens. Abhandlungen der Bayerische Akademie der Wissenschaften, Mathematisch-Naturwissenschaftliche Klasse, 1928; 32(1): 48-53.

\section{ПІЗНЬОМІОЦЕНОВІ КОСТИСТІ РИБИ}

\section{3 МІСЦЕЗНАХОДЖЕННЯ ПОКШЕШТИ (РЕСПУБЛІКА МОЛДОВА)}

\section{О. М. Ковальчук', В. А. Марарескул", Т. Ф. Обаде}

${ }^{1}$ Національний науково-природничий музей НАН України вул. Б. Хмельницького, 15, Київ 01601, Україна

${ }^{2}$ Державна служба геології і надрокористування Придністровської Молдовської Республіки вул. Юності, 58/3, Тирасполь, МD-3300

${ }^{3} /$ нститут зоології АН Республіки Молдова вул. Академічна, 1, Кишинеу 2028, Республіка Молдова e-mail: Biologiest@ukr.net

Ізольовані глоткові та щелепні зуби костистих риб, а також численні кістки інших хребетних тварин, датовані пізнім міоценом (серединою пізнього сармату = раннім 
тортоном, 9,8 млн р.т.), були знайдені в алювіальних відкладах місцезнаходження Покшешти (Республіка Молдова). Установлено наявність решток шести таксонів риб, які описані у статті; більшість із них (4 види) є представниками родини Суprinidae. Таксономічний список включає також осетрових (Acipenseridae gen. et sp. indet.) і щукоподібних (Esox sp.). Змішаний характер фауни, сумісне знаходження прісноводних і морських видів дає змогу висловити припущення, що захоронення решток відбувалось у безпосередній близькості від крупного морського басейну в річковій авандельті. Угруповання риб із Покшешт виявляє подібність до інших місцезнаходжень раннього тортону Європи і $€$ відображенням палеобіогеографічних змін на території Паратетису протягом пізнього міоцену.

Ключові слова: костисті риби, пізній міоцен, сармат, MN 10, Покшешти, Східна Європа.

\title{
ПОЗДНЕМИОЦЕНОВЫЕ КОСТИСТЫЕ РЫБЫ ИЗ МЕСТОНАХОЖДЕНИЯ ПОКШЕШТЫ (РЕСПУБЛИКА МОЛДОВА)
}

\author{
А. Н. Ковальчук', В. А. Марарескул², Т.Ф. Обадэ \\ ${ }^{1}$ Национальный научно-природоведческий музей НАН Украины \\ ул. Б. Хмельницкого, 15, Киев 01601 Украина \\ 2 Государственная служба геологии и недропользования \\ Приднестровской Молдавской Республики, ул. Юности, 58/3, Тирасполь, MD-3300 \\ ${ }^{3}$ Институт зоологии АН Республики Молдова \\ ул. Академическая, 1, Кишинэу 2028, Республика Молдова \\ e-mail: Biologiest@ukr.net
}

Изолированные глоточные и челюстные зубы костистых рыб, а также многочисленные кости других позвоночных, датированные поздним миоценом (серединой позднего сармата = ранним тортоном, 9,8 млн л.н.), были обнаружены в аллювиальных отложениях местонахождения Покшешты (Республика Молдова). Установлено наличие остатков шести таксонов рыб, которые описаны в статье; большинство из них (4 вида) являются представителями семейства Cyprinidae. Tаксономический список включает также осетровых (Acipenseridae gen. et sp. indet.) и щукообразных (Esox sp.). Смешанный характер фауны, совместное наличие пресноводных и морских видов позволяют предположить, что захоронение остатков происходило в непосредственной близости от крупного морского бассейна в речной авандельте. Сообщество рыб из Покшешт проявляет сходство с другими местонахождениями раннего тортона Европы и является отражением палеобиогеографических изменений на территории Паратетиса на протяжении позднего миоцена.

Ключевые слова: костистые рыбы, поздний миоцен, сармат, MN 10, Покшешты, Восточная Европа.

Одержано: 09.02.2014

ISSN 1996-4536 (print) • ISSN 2311-0783 (on-line) • Біологічні Студії / Studia Biologica • 2014 • Том 8/№2 • C. 149-156 